\title{
Motivation and Regular Salary as Determinants of Agricultural Science Teacher's Commitment and Accomplishment of their Professional Responsibilities in Rivers State, Nigeria
}

\author{
Salome Emeya \\ Department of Agricultural Science, Faculty of Vocational \& Technical \\ Education, Ignatius Ajuru University of Education, \\ Port Harcourt, Rivers State, Nigeria
}

Ekong O. Antiaobong, PhD

Department of Vocational Education, University of Uyo,

Akwa Ibom State, Nigeria

doi: 10.19044/esj.2016.v12n13p168 URL:http://dx.doi.org/10.19044/esj.2016.v12n13p168

\section{Abstract}

The study examined motivation and regular salary as determinants of agricultural science teachers' commitment in Port Harcourt Local Government Area of Rivers State, Nigeria. Survey and correlational research designs were adopted. A sample size of 142 subjects was used in this study. This comprised of 96 Agricultural Science teachers in both junior and senior secondary schools in Port Harcourt, 12 Principals, 24 Vice Principals in both junior and senior secondary schools in Port Harcourt, and 10 Supervisors in Port Harcourt. The Teachers' Motivation Inventory (TMI), Teachers' Regular Salary Scale (TRESS), and Agricultural Science Teachers' Commitment Questionnaire (ASTCQ) instruments were used. The instruments were validated by experts in Education and Agricultural Science. The reliability of the instruments was established using the Cronbach Alpha method to obtain indices of 951, .902, and .844 for the TMI, TRESS and ASTCQ instruments, respectively. Data obtained from the 129 copies of the TMI, TRESS, and ASTCQ instruments was analyzed using multiple linear regression analysis. The result revealed that motivation and regular payment of salary jointly contributes to Agricultural Science teachers' commitment in Port Harcourt Local Government Area of Rivers State. Furthermore, government ensuring the teachers' regular promotion, alongside providing teachers' with incentives like bonuses, class attendance and practical allowances etc., were among the proffered recommendations. This was 
targeted at increasing Agricultural Science teachers’ level of commitment in secondary schools.

Keywords: Motivation, Regular Salary, Agricultural Science Teachers Commitment, Professional responsibilities

\section{Introduction}

Motivation and regular payment of teacher's salary is usually in the form of reward, bonuses, profit sharing plans, and pension plans. Thus, these include redundancy, retirement benefits, and employees' stock ownership plans. Other incentive systems facilitate teachers' effective discharge of their responsibilities of grooming students and in the actualization of the goals of education (Idio, 2008). In other words, the reward systems available to the teaching profession go a long way to determine how teachers perform their job. Incentive system in any organization is a means of sustaining those workers on the job. However, it is a motivating factor that influences the attitude of the worker on the job (Ben, 2014a). Motivation as an index of performance is determined by three crucial factors: ability (able to do a job), motivation (want to or willingness to do a job), and role clarity (understanding what the job is). Agricultural science teachers in secondary schools, like employees of any other levels of education, needs to be motivated. Thus, this will help them to improve the performance of teachers, and usher in the positive attitude and mental balance that enhances the teachers' capacity to impact knowledge on students, meet individual needs, and also achieve the institutional goals of improving the quality of education in the nation (Bosompem et al., 2012).

Agricultural science teacher's, among other major stakeholders in agriculture, need to be motivated to train the future agriculturists and the agricultural policy makers of the nation. Unfortunately, lack of incentives and pay are not commensurable to the tedious nature of the work engaged by Agricultural Science teachers. Therefore, these have heightened the agitations and demands for the improvement in salary and other work conditions. Furthermore, this culminates into strike actions that normally affect the students and, consequently, the future leaders and frontiers of agriculture and national development (Adelabu, 2005). Commenting on the elements of motivation, Bosompem et al. (2012) posits that better working condition contemplates. However, they are not limited to providing accurate and regular information concerning teachers; dealing with teachers' personal problems in a sympathetic and positive manner; improving teachers working conditions; and quick discussion, response, and decisions on teachers' problems. Others include management fulfilling the promises made to teachers; providing adequate health insurance coverage for teachers; giving 
teachers adequate workload that provides positive satisfying pleasure for them, their colleagues, and students; teachers receiving adequate remuneration for their job; providing teachers' with all the tools and materials to effectively teach agriculture in secondary schools; and providing first aid in times of accident.

Bosompem et al. (2012) also emphasized that promotion (via steady movement of teachers' to the next level and next grade internally and externally) in the service with commensurate or significant improvements in work conditions will lead to the motivation and job satisfaction of teachers. Sirima \& Poipoi (2010) reported that public secondary school teachers with high levels of job satisfaction tend to have high social and psychological atmosphere in the classroom. Thus, this results in high productivity and effectiveness in the job performance and willingness to stay longer. Therefore, efforts at improving teachers' motivation must include improving teacher's working conditions, recognition, involvement in decision making, high sense of involvement in students learning, participation in goal setting, and job satisfaction (Abassi \& Hollman, 2000; Ali \& Ahmed, 2009). In a related study, Shadid (2014) concluded that salaries constitute a significant part of the overall cost in any organization. He stated that establishment which lacks the ability to pay wages and salaries regularly, as in the case of the teaching profession, are in danger of disintegration. He emphasized that poor salaries is a constant source of frustration and can result to decline in productivity. Therefore, the ability of government to satisfy teachers' needs goes a long way to determine the attitude they would have towards their job to a great extent. This, by implication, means that teachers' attitude towards their job is a function of the extent to which they are satisfied with their salaries.

Despite the challenges of limited availability of fund, regular salary and other financial incentives, of no doubt, undermine the ability to motivate teachers towards their positive job disposition, positive job attitude, greater productivity, higher commitment, and positive students' achievement (Ortyoyande \& Agbe, 2005). Ubon in Ben (2014b) reported that for any incentive scheme to be effective, it must meet the following basic fundamentals; firstly, the scheme should be fair to both employer and employees to ensure complete trust on both sides. Secondly, the work content must be accurately measured, and the workers should be paid in direct proportion to the individual effort rather than as a group. Thirdly, the scheme should be simple in operation, flexible, intimately connected to other management controls, and should contain as much promotion for the slow and fast workers among others. Ferdiman (2007) emphasized that increased student behaviour, efficient learning, and performance can be aroused, sustained, directed, and selectively reinforced by a highly committed teacher. 
Therefore, competent teachers' motivation and salary is seen as a hypothesized cause of teacher productivity, push for teachers' commitment and efficiency, and the determinant of teachers' behaviours, arousal, vigour, direction, and persistence (Leslie, 2014). Furthermore, lack of motivation and irregular payment of salary to teachers have been responsible for the apathy and low morale in the teaching job; thus, this could ultimately result to poor work role and negative work disposition (Ehondor \& Omoruyi, 2013). Chiang \& Birtch (2010) discovered that salary and fringe benefits are important elements of interest to teachers; they dictate the tempo of the teaching job; increases teachers' commitment in the job of teaching; leads students to likely record better grades; increases teachers job disposition when their physiological needs like food, clothing and shelter are met; increases teachers self-esteem; and it make teachers active and responsible to their school work.

Furthermore, Gabrielle \& Hogan (2013) in their study on teachers' condition of service and teachers' competence, revealed that better salarypackage and fringe benefits leads to teachers': putting more effort at work, preparing adequately for their lessons, attending school regularly, punctuality to school, attending classes on schedule, teaching the students well, administering, marking, and recording assignments, test, and examinations.

Most importantly, regular salary and fringe benefits help teachers to focus more attention on their primary work role, become independent, adequately cater for their family members, meet other needs and values in life, and increase their self-perception and status in the society (Gabrielle \& Hogan, 2013). Similarly, Idio (2008) observed that allowances in secondary schools are geared towards providing teachers with special or extra fund or bonus for extra lesson, agricultural practical sessions or classes, form or class teachers' allowance, effectively carrying out school work, committees to perform other duties, and working extra hours. Ortyoyande \& Agbe (2005) pointed out that motivation and regular salary was very paramount in hypothesizing the physiological needs (food, clothing and shelter etc.) for the proper mental and body functioning of Agricultural Science teachers whose expected persistency and productivity offers the direction that facilitates students' academic achievement.

Therefore, Gawel (2013) in his analysis of Maslow's hierarchy of needs identified the physiological needs as the most basic needs that are necessary for the proper functioning of the body. In addition, it is necessary for subsequent meeting of other higher levels of needs. The satisfaction of the physiological needs in respect of the teachers is tied to financial remuneration. Based on the opinion of Dewhurst, Guthridge \& Mohr (2010), every person is motivated to obtain recognition and self-esteem. However, their take home pay is an important determinant of how his needs will be 
satisfied. This position aligns with John (2006) whose study on the applicability of Maslow's need theory among teachers in Akwa Ibom State revealed that; teachers valued the satisfaction of Physiological needs for competence and efficiency in job performance; motivation; and social and self-actualization. Furthermore, effective teacher motivation and regular salary enhances the commitment of Agricultural Science teachers to regularly write notes of lesson, inculcate positive attitude to work, prepare assessment records, mark class register correctly and regularly, professionally teach students, actualizing organizational goals, acquisition of professional training, properly evaluate students' performance in examinations, and justify the financial rewards and the continual maintenance of good performance for more expected rewards. Interestingly, increased commitment also helps the Agricultural Science teachers to assist in establishing new school farms, equipping libraries with adequate agricultural science textbooks, providing well-equipped laboratories, and initiating programmes for improved students learning and the required positive results (Bosompem et al., 2012). This study identify various factors that affect teacher's motivation which could serve as a guide for policy formulation, and commitment and performance from a properly motivated, recognized, and respected Agricultural Science teachers.

\section{Statement of Problem}

The indispensable and noble profession of teaching is confronted with the problem of poor morale, low and late payment of salary, infrastructural deficit (like well-equipped laboratories, school farms, libraries etc.), incommensurate reward for the extent of work, low budget or funding of school operations, constant agitation for salary increase, haphazard implementation of reports or goals, incentives, and better working conditions. Therefore, this leads to poor planning and disillusionment of teachers (including, Agricultural Science). Also, it further translates into inefficient professional conducts and students' underachievement in Nigeria.

These problems prompted the researcher into investigating motivation and regular salary as determinants of agricultural science teachers' commitment in Port Harcourt Local Government Area of Rivers State, Nigeria. Consequently, this is in a view at x-raying how promotion, job satisfaction, working environment, incentives, fringe benefits, and allowances will lead to an optimized Agricultural Science teacher's commitment and job performance in secondary schools.

\section{Purpose of the Study}

The purpose of the study is to assess how motivation and regular salary can be a determinant to Agricultural Science teachers' commitment 
and how these can help to accomplish their professional responsibilities in Port Harcourt Local Government Area of Rivers State, Nigeria.

Specifically, this study intends to:

1. Determine the relative contribution of motivation variables via promotion, job satisfaction, and working condition to Agricultural Science teachers' commitment and accomplishment of their professional responsibilities in Port Harcourt Local Government Area of Rivers State.

2. Determine the joint contribution of motivation variables via promotion, job satisfaction, and working condition to Agricultural Science teachers' commitment and accomplishment of their professional responsibilities in Port Harcourt Local Government Area of Rivers State.

3. Determine the relative contribution of regular payment of salary variables via incentives and fringe benefits to Agricultural Science teachers' commitment and accomplishment of their professional responsibilities in Port Harcourt Local Government Area of Rivers State.

4. Determine the joint contribution of regular payment of salary variables via incentives and fringe benefits to Agricultural Science teachers' commitment and accomplishment of their professional responsibilities in Port Harcourt Local Government Area of Rivers State.

5. Determine the relative contribution of motivation and regular payment of salary to Agricultural Science teachers' commitment and accomplishment of their professional responsibilities in Port Harcourt Local Government Area of Rivers State.

6. Determine the joint contribution of motivation and regular payment of salary to Agricultural Science teachers' commitment and accomplishment of their professional responsibilities in Port Harcourt Local Government Area of Rivers State.

\section{Research Questions}

The following research questions guided the study:

1. What is the relative contribution of motivation variables to Agricultural Science teachers' commitment and accomplishment of their professional responsibilities in Port Harcourt Local Government Area of Rivers State?

2. What is the joint contribution of motivation variables to Agricultural Science teachers' commitment and accomplishment of their professional responsibilities in Port Harcourt Local Government Area of Rivers State?

3. What is the relative contribution of regular payment of salary variables to Agricultural Science teachers' commitment and accomplishment of their professional responsibilities in Port Harcourt Local Government Area of Rivers State? 
4. What is the joint contribution of regular payment of salary variables to Agricultural Science teachers' commitment and accomplishment of their professional responsibilities in Port Harcourt Local Government Area of Rivers State?

5. What is the relative contribution of motivation and regular payment of salary to Agricultural Science teachers' commitment and accomplishment of their professional responsibilities in Port Harcourt Local Government Area of Rivers State?

6. What is the joint contribution of motivation and regular payment of salary to Agricultural Science teachers' commitment and accomplishment of their professional responsibilities in Port Harcourt Local Government Area of Rivers State?

\section{Significance of the Study}

Consequently, this study is beneficial to the teachers, principals, community, curriculum planners, educators, government, and the society at large. The motivational variables will help the teachers to be committed to their jobs thereby accomplishing their professional responsibilities. The findings of this study will also encourage the Nigeria Union of Teachers (NUT) in Rivers State to enter into dialogue with the state government in order to negotiate better pay package and other incentives. Furthermore, the school community and the agricultural science teachers would develop and maintain a functional and mutual relationship between themselves. Also, curriculum planners, educators, and the government would use the results of this study to improve secondary school system.

\section{Methodology}

The study was carried out in Port Harcourt Local Government Area of Rivers State, Nigeria. Furthermore, motivation (via: promotion, job satisfaction, and working condition) and salary (via: incentives and fringe benefits) are the independent variables. On the other hand, agricultural science teachers' commitment (via: attitude to teaching and supervision) is the dependent variable. The study adopted the descriptive survey and correlational research designs. The population of the study consists of all Agricultural Science teachers, Principals and Vice Principals in all the junior and senior secondary schools, and all Supervisors in Port Harcourt Local Government Area of Rivers State. Purposive sampling technique was used in the selection of 1 Principal, 2 Vice Principals, and 4 Agricultural Science teachers from each of the 12 junior and senior secondary schools in Port Harcourt Local Government Area of Rivers State. Furthermore, random sampling technique was used in the selection of ten (10) supervisors in Port Harcourt Local Government Area. Thus, this constitutes a sample of one 
hundred and forty-two (142) respondents. These respondents are made up of 12 Principals, 24 Vice Principals, 96 Agricultural Science teachers, and 10 Supervisors.

The instruments for data collection were the Teachers' Motivation Inventory (TMI), Teachers' Regular Salary Scale (TRESS), and the Agricultural Science Teachers’ Commitment Questionnaire (ASTCQ) made up of 32, 20 and 22 items, respectively. Furthermore, they were validated by experts in Education and Agricultural Science Department. The instruments were patterned after a modified rating scale of "Strongly Agree”, "Agree”, "Disagree", and "Strongly Disagree". The reliability of the instruments was established using the Cronbach Alpha method to obtain indices of .951, .902, and .844 for the TMI, TRESS and ASTCQ instruments, respectively. Out of the 142 copies of the TMI, TRESS and ASTCQ instruments was administered to the respondents. However, only 129 valid copies was retrieved. In addition, they were subsequently used for analysis using multiple linear regression analysis.

\section{Results}

Table 1. Summary of Multiple Linear Regression Analysis on the relative contribution of motivation variables to Agricultural Science teachers' commitment and Accomplishment of their Professional Responsibilities in Port Harcourt Local Government Area of Rivers State

\begin{tabular}{|c|c|c|c|c|c|c|}
\hline & \multirow[t]{2}{*}{ Model } & \multicolumn{2}{|c|}{$\begin{array}{c}\text { Unstandardized } \\
\text { Coefficients } \\
\end{array}$} & \multirow{2}{*}{\begin{tabular}{|c|}
$\begin{array}{l}\text { Standardized } \\
\text { Coefficients }\end{array}$ \\
Beta
\end{tabular}} & \multirow[t]{2}{*}{$\mathrm{T}$} & \multirow[t]{2}{*}{ Sig. } \\
\hline & & B & $\begin{array}{l}\text { Std. } \\
\text { Error }\end{array}$ & & & \\
\hline \multirow{4}{*}{1} & (Constant) & 40.666 & 5.674 & & 7.166 & .000 \\
\hline & Promotion & .358 & .198 & .198 & 1.808 & $.073^{\#}$ \\
\hline & Job Satisfaction & .323 & .170 & .197 & 1.902 & $.060^{\#}$ \\
\hline & $\begin{array}{l}\text { Working } \\
\text { Condition }\end{array}$ & .086 & .145 & .064 & .593 & $.555^{\#}$ \\
\hline
\end{tabular}

a. Dependent Variable: Agricultural Science Teacher's Commitment

*Significant at p-value $<0.05{ }^{\#}$ Not Significant at p-value $>0.05$

Table 1 shows that none of the three (3) predictor's variables of motivation independently did not contribute statistically and significantly to Agricultural Science teachers' commitment in Port Harcourt Local Government Area of Rivers State. These variables that did not contribute to the model are: promotion $\left[\beta=.358, \mathrm{t}_{(185)}=1.808, \mathrm{p}>.05\right]$, job satisfaction $[\beta$ $\left.=.323, \mathrm{t}_{(185)}=1.902, \mathrm{p}>.05\right]$, and working condition $\left[\beta=.086, \mathrm{t}_{(185)}=.593\right.$, p> .05]. 
Table 2. Summary of Multiple Linear Regression Analysis on the joint contribution of motivation variables to Agricultural Science teachers' commitment and Accomplishment of their Professional Responsibilities in Port Harcourt Local Government Area of Rivers State

\begin{tabular}{|c|c|c|c|c|c|c|}
\hline Source & $\begin{array}{c}\text { Sum of } \\
\text { Squares } \\
(\mathrm{SS})\end{array}$ & Df & $\begin{array}{c}\text { Mean } \\
\text { Square }\end{array}$ & $\begin{array}{c}\text { F. } \\
\text { Ratio }\end{array}$ & $\begin{array}{c}\text { P- } \\
\text { value }\end{array}$ & Remark \\
\hline Regression & 1888.659 & 1 & 1888.659 & 21.574 & $.000^{\mathrm{b}}$ & $\mathrm{S}$ \\
\hline Residual & 11117.900 & 127 & 87.543 & & \\
\hline Total & 13006.558 & 128 & & & \\
\hline \multicolumn{7}{c}{$\begin{array}{c}\text { Multiple R }\left(\mathrm{r}_{\mathrm{p}}\right)=.381^{\mathrm{a}} \\
\text { R. Square }\left(\mathrm{r}^{2}\right)=.145 \\
\text { Adjusted } \mathrm{R}^{2}=.138 \\
\text { Standard Error of Estimate }=9.35642\end{array}$} \\
\hline
\end{tabular}

Table 2 shows that the use of the three motivation variables (via: promotion, job satisfaction, and working condition) to predict Agricultural Science teachers' commitment in Port Harcourt Local Government Area of Rivers State yielded a coefficient of multiple regression R (rp) of 0.381 and a multiple regression square $\left(\mathrm{R}^{2}\right)$ of 0.145 . This also shows that $\mathrm{F}$ is 21.574 , which is significant at $\mathrm{P}<0.05$. This is because the value of $\mathrm{P}$ is less than 0.05 . Therefore, the three (3) predictors' variables of motivation jointly contribute statistically and significantly to Agricultural Science teachers' commitment in Port Harcourt Local Government Area of Rivers State.

Subsequently, this shows that motivation accounted for 15 percent of the variance in Agricultural Science teachers' commitment in Port Harcourt Local Government Area of Rivers State. In other words, $15 \%$ of the variance in the change in the Agricultural Science teachers' commitment in Port Harcourt Local Government Area of Rivers State can be explained by pulling the different variables of motivation together. This means that $85 \%$ of the variation in Agricultural Science teachers' commitment in Port Harcourt Local Government Area of Rivers State cannot be explained by motivation variables alone. Thus, there must be other variables that must have influenced Agricultural Science teachers' commitment in Port Harcourt Local Government Area of Rivers State also.

Table 3. Summary of Multiple Linear Regression Analysis on the relative contribution of regular payment of teachers' variables to Agricultural Science teachers' commitment and Accomplishment of their Professional Responsibilities in Port Harcourt Local Government Area of Rivers State

\begin{tabular}{|cc|c|c|c|c|l|}
\hline \multirow{2}{*}{ Model } & \multicolumn{2}{|c|}{$\begin{array}{c}\text { Unstandardized } \\
\text { Coefficients }\end{array}$} & $\begin{array}{l}\text { Standardized } \\
\text { Coefficients }\end{array}$ & \multirow{2}{*}{ Sig. } \\
\cline { 2 - 4 } & B & Std. Error & Beta & & \\
\hline \multirow{2}{*}{1} & (Constant) & 55.904 & 4.711 & & 11.867 & .000 \\
& Incentives & .160 & .151 & .112 & 1.059 & $.292^{\#}$ \\
\cline { 2 - 5 } & Fringe Benefits & .116 & .158 & .078 & .735 & $.464^{\#}$ \\
\hline
\end{tabular}

a. Dependent Variable: Agricultural Science Teacher's Commitment

* Significant at p-value $<0.05{ }^{\#}$ Not Significant at p-value $>0.05$ 
Table 3 shows that none of the two (2) predictors variables of regular payment of salary independently did not contribute statistically and significantly to Agricultural Science teachers’ commitment in Port Harcourt Local Government Area of Rivers State. However, these variables that did not contribute to the model are: incentives $\left[\beta=.160, \mathrm{t}_{(185)}=1.059, \mathrm{p}>.05\right]$ and fringe benefits $\left[\beta=.116, \mathrm{t}_{(185)}=.735, \mathrm{p}>.05\right]$.

Table 4. Summary of Multiple Linear Regression Analysis on the joint contribution of regular payment of salary variables to Agricultural Science teachers' commitment and Accomplishment of their Professional Responsibilities in Port Harcourt Local Government

\begin{tabular}{|c|c|c|c|c|c|c|}
\hline \multicolumn{7}{|c|}{ Area of Rivers State } \\
\hline Source & $\begin{array}{l}\text { Sum of } \\
\text { Squares } \\
\text { (SS) }\end{array}$ & $\overline{\mathrm{Df}}$ & $\begin{array}{c}\text { Mean } \\
\text { Square }\end{array}$ & $\begin{array}{c}\text { F. } \\
\text { Ratio }\end{array}$ & $\begin{array}{c}\mathrm{P}- \\
\text { value }\end{array}$ & Remark \\
\hline Regression & 365.355 & 1 & 365.355 & \multirow[t]{3}{*}{3.671} & \multirow[t]{3}{*}{$.058^{\mathrm{b}}$} & \multirow[t]{3}{*}{ NS } \\
\hline Residual & 12641.203 & 127 & 99.537 & & & \\
\hline Total & 13006.558 & 128 & & & & \\
\hline \multicolumn{7}{|c|}{$\begin{array}{r}\text { Multiple } \mathrm{R}\left(\mathrm{r}_{\mathrm{p}}\right)=.168^{\mathrm{a}} \\
\text { R. Square }\left(\mathrm{r}^{2}\right)=.028 \\
\text { Adjusted } \mathrm{R}^{2}=.020 \\
\text { Standard Error of Estimate }=9\end{array}$} \\
\hline
\end{tabular}

Table 4 shows that the use of the two regular payment of salary variables (via: incentives and fringe benefits) to predict Agricultural Science teachers' commitment in Port Harcourt Local Government Area of Rivers State yielded a coefficient of multiple regression R (rp) of 0.168 and a multiple regression square $\left(\mathrm{R}^{2}\right)$ of 0.028 . This also shows that $\mathrm{F}$ is 3.671 which is not significant at $\mathrm{P}>0.05$. This is because the value of $\mathrm{P}$ is greater than 0.05 . Therefore, the two (2) predictors' variables of regular payment of salary jointly did not contribute statistically and significantly to Agricultural Science teachers' commitment in Port Harcourt Local Government Area of Rivers State.

Subsequently, this shows that regular payment of salary accounted for 3 percent of the variance in Agricultural Science teachers' commitment in Port Harcourt Local Government Area of Rivers State. In other words, 3\% of the variance in the change in the Agricultural Science teachers' commitment in Port Harcourt Local Government Area of Rivers State can be explained by pulling the different variables of regular payment of salary together. This means that $97 \%$ of the variation in Agricultural Science teachers' commitment in Port Harcourt Local Government Area of Rivers State cannot be explained by regular payment of salary variables alone. Thus, there must be other variables that must have influenced Agricultural Science teachers' commitment in Port Harcourt Local Government Area of Rivers State also. 
Table 5. Summary of Multiple Linear Regression Analysis on the relative contribution of motivation and regular payment of salary to Agricultural Science teachers' commitment and Accomplishment of their Professional Responsibilities in Port Harcourt Local Government Area of Rivers State

\begin{tabular}{|cc|c|c|c|c|c|}
\hline \multirow{2}{*}{ Model } & \multicolumn{2}{|l|}{ Unstandardized Coefficients } & $\begin{array}{c}\text { Standardized } \\
\text { Coefficients }\end{array}$ & \multirow{2}{*}{ S } & \\
\cline { 2 - 5 } & B & Std. Error & Beta & & \\
\hline \multirow{4}{*}{1} & (Constant) & 41.164 & 5.503 & & 7.481 & .000 \\
& Motivation & .303 & .068 & .488 & 4.431 & $.000^{*}$ \\
& Regular Salary & -.132 & .091 & -.159 & -1.445 & $.151^{\#}$ \\
\hline
\end{tabular}

a. Dependent Variable: Agricultural Science Teacher's Commitment *Significant at p-value $<0.05{ }^{\text {\# }}$ Not Significant at p-value $>0.05$

Table 5 shows that motivation independently contributed statistically and significantly to Agricultural Science teachers' commitment in Port Harcourt Local Government Area of Rivers State. On the other hand, regular salary independently did not contribute statistically and significantly to Agricultural Science teachers' commitment in Port Harcourt Local Government Area of Rivers State. However, the variable that contribute to the model is motivation $\left[\beta=.303, \mathrm{t}_{(185)}=4.431, \mathrm{p}<.05\right]$, while the variable that did not contribute to the model is regular salary $\left[\beta=-.132, \mathrm{t}_{(185)}=-\right.$ $1.445, \mathrm{p}>.05]$.

Table 6. Summary of Multiple Linear Regression Analysis on the joint contribution of motivation and regular payment of salary to Agricultural Science teachers' commitment and Accomplishment of their Professional Responsibilities in Port Harcourt Local

Government Area of Rivers State

\begin{tabular}{|c|c|c|c|c|c|c|}
\hline Source & $\begin{array}{c}\text { Sum of } \\
\text { Squares } \\
(\mathrm{SS})\end{array}$ & Df & $\begin{array}{c}\text { Mean } \\
\text { Square }\end{array}$ & F. Ratio & $\begin{array}{c}\text { P- } \\
\text { value }\end{array}$ & Remark \\
\hline Regression & 8871.253 & 1 & 8871.253 & 272.446 & $.000^{\mathrm{b}}$ & S \\
\hline Residual & 4135.305 & 127 & 32.561 & & \\
\hline Total & 13006.558 & 128 & & \\
\hline \multicolumn{7}{c|}{$\begin{array}{c}\text { Multiple } \mathrm{R}\left(\mathrm{r}_{\mathrm{p}}\right)=.826^{\mathrm{a}} \\
\text { R. Square }\left(\mathrm{r}^{2}\right)=.682 \\
\text { Adjusted } \mathrm{R}^{2}=.680 \\
\text { Standard Error of Estimate }=5.70626\end{array}$} \\
\hline
\end{tabular}

Table 6 shows that the use of motivation and regular payment of salary to predict Agricultural Science teachers' commitment in Port Harcourt Local Government Area of Rivers State yielded a coefficient of multiple regression $R$ (rp) of 0.826 and a multiple regression square $\left(\mathrm{R}^{2}\right)$ of 0.682 . This also shows that $F$ which is 272.446 was significant at $\mathrm{P}<0.05$. This is because the value of $\mathrm{P}$ is less than 0.05 . Therefore, motivation and regular payment of salary jointly contribute statistically and significantly to 
Agricultural Science teachers' commitment in Port Harcourt Local Government Area of Rivers State.

Subsequently, this shows that motivation and regular payment of salary accounted for 68 percent of the variance in Agricultural Science teachers’ commitment in Port Harcourt Local Government Area of Rivers State. In other words, $68 \%$ of the variance in the change in the Agricultural Science teachers' commitment in Port Harcourt Local Government Area of Rivers State can be explained by pulling the different variables of motivation and regular payment of salary together. This means that $32 \%$ of the variation in Agricultural Science teachers' commitment in Port Harcourt Local Government Area of Rivers State cannot be explained by motivation and regular payment of salary alone. Thus, there must be other variables that must have influenced Agricultural Science teachers' commitment in Port Harcourt Local Government Area of Rivers State also.

\section{Discussion of Findings}

The result in table 1 revealed that the three (3) predictors variables of motivation (via: promotion, job satisfaction, and working condition) independently did not contribute statistically and significantly to Agricultural Science teachers' Commitment. In turn, it does not allow them to achieve their professional responsibilities in Port Harcourt Local Government Area of Rivers State. Therefore, this finding is in agreement with the views of scholars' like Diamond (2012) who identified that economic disadvantages and lack of prospects for promotion as negative factors are militating against teachers' motivation and effective performance. Idio (2008) posited that teacher's regard for satisfaction needs via basic need, needs of security, social esteem, autonomy, and self-actualization are very important in boosting teachers' commitment when these needs are sufficiently met. Also, Chamundeswari (2013) posited conducive working condition as a prospect for teachers' affective commitment and a potential moderator for a healthy and successful relationship in secondary schools.

The result in table 2 revealed that the three (3) predictors variables of motivation (via: promotion, job satisfaction, and working condition) jointly contributes statistically and significantly to Agricultural Science teachers' commitment. In turn, it allows them to achieve their professional responsibilities in Port Harcourt Local Government Area of Rivers State. This finding is consistent with the submissions of Indhumathi (2011) who found that there was a significant relationship between conducive working condition and Agricultural Science teachers' effectiveness and commitment. Thus, this is basically seen as a job performance indicator in secondary schools. Hence, the ability of government to satisfy teachers' needs and working conditions goes a long way to influence the extent of the attitude 
and commitment they would have for their job (Ben, 2014b). This finding further supports the position of Holmes (2012) in her study on teachers' competence and professional achievement. This is because academic specialists depend on how they are motivated by the government via promotion and condition of service.

The result in table 3 revealed that the two (2) predictors' variables of regular payment of salary (via: incentives and fringe benefits) independently did not contribute statistically and significantly to Agricultural Science teachers' commitment. In turn, it does not allow them to achieve their professional responsibilities in Port Harcourt Local Government Area of Rivers State. This finding contradicts earlier assertion by Olukoya (2013) who pointed out that incentive and the basic fringe benefits of teachers at whatever category to a large extent effectively motivates teachers.

The result in table 4 revealed that the two (2) predictors' variables of regular payment of salary (via: incentives and fringe benefits) jointly did not contribute statistically and significantly to Agricultural Science teachers' commitment in Port Harcourt Local Government Area of Rivers State. This finding aligns with Olukoya (2013) which states that the regularity of salary, incentives, and fringe benefits motivates teachers to the extent to which they discharge their professional responsibilities.

The result in table 5 revealed that motivation independently contributes statistically and significantly to Agricultural Science teachers' commitment in Port Harcourt Local Government Area of Rivers State. On the other hand, regular salary independently did not contribute statistically and significantly to Agricultural Science teachers' commitment. In turn, it does not allow them achieve their professional responsibilities in Port Harcourt Local Government Area of Rivers State. This finding is consistent with Ben (2014b) who emphasized that motivation is paramount for enhanced teacher's high level performance, attitude to work, punctuality, feedback and evaluation, commitment to work, and attitude towards teaching. Thus, on the contrary, Ortyoyande \& Agbe (2005) pointed out that salary was very paramount to teachers' performance. This is because salaries via incentives (wages, bonuses, profit sharing plans, pension plans) and fringe benefits (redundancy, and retirement benefits and employees' stock ownership plans) constitute the main financial strategy for rewarding teachers' commitment (Idio, 2008).

The result in table 6 revealed that motivation and regular payment of salary jointly contributes to Agricultural Science teachers' commitment. In turn, it allows them to achieve their professional responsibilities in Port Harcourt Local Government Area of Rivers State. This finding is supported by earlier findings by Ferdiman's (2007) which states that students' learning disposition can be aroused, sustained, directed, and selectively reinforced by 
a highly committed and well-motivated teachers. On the other hand, salary was hypothesized as the cause of teachers' productivity and the determinant of teachers' arousal, vigor, direction, persistence, and "push" for teachers' competence. Thus, any organization that lacks the ability to pay salaries regularly, as in the case of the teaching profession, is in danger of disintegration (Littlehood, 2012). This is because poor salaries are a constant source of frustration which can result in declines to productivity (Ben, 2014b).

\section{Conclusion}

The study concluded that the three (3) predictor variables of motivation (via: promotion, job satisfaction, and working condition) and the two (2) predictor variables of regular payment of salary (via: incentives and fringe benefits), when considered separately, did not contribute to Agricultural Science teachers' commitment. As a result, this thereby makes the accomplishment of their professional responsibilities to lag behind in Port Harcourt Local Government Area of Rivers State. This means that considering any form of motivation and regular salary in isolation will not lead to Agricultural Science teachers' commitment to their professional responsibilities in secondary schools in Port Harcourt Local Government Area of Rivers State.

Furthermore, the three (3) predictor variables of motivation (via: promotion, job satisfaction, and working condition) and the two (2) predictor variables of regular payment of salary (via: incentives and fringe benefits), when considered, jointly contributes to Agricultural Science teachers' commitment in Port Harcourt Local Government Area of Rivers State. This means that the adequacy of motivation (promotion, job satisfaction, and working condition) and regularity of salary (incentives and fringe benefits) together increases Agricultural Science teachers' level of commitment. Consequently, this makes them to professionally discharge their responsibilities in secondary schools in Port Harcourt Local Government Area of Rivers State.

\section{Recommendations}

Based on the findings of the study, the following recommendations were proffered:

1. The government should ensure that regular promotion is guaranteed to agricultural science teacher's, as a way of increasing their commitment.

2. Agricultural science teachers' should be given the opportunity to freely use their skills and competence in teaching that stimulates students' curiosity and interest in the learning of agricultural science. 
3. Agricultural science teachers' should be accorded the respect they deserve to enhance their satisfaction with the teaching job.

4. In order to improve the working conditions in secondary schools, Agricultural Science teachers should be provided with the right infrastructures, laboratories, school farm and farming equipment, respectively.

5. Agricultural Science teachers should be provided with incentives like bonuses and practical allowances in order to increase their level of commitment to their work.

6. The government should ensure that agricultural science teachers are paid better salary package and on time, to satisfy their basic and pressing needs in life. This will enable them to have confidence in their job and work hard to ensure high job delivery.

7. Finally, the government and relevant authorities are called upon to adopt motivation and regular payment of teachers' salary as an essential determinant of Agricultural Science teachers' commitment in secondary schools.

\section{References:}

Abassi \& Hollman (2000). Turnover the real bottom line. Public Personnel Management, 29(3), 333-342.

Adelabu (2005). Teacher motivation and incentives in Nigeria. A Journal of Basic Education in Nigeria. 5(2), 1-24

Ali \& Ahmed (2009). The Impact of Reward and Recognition Programs on Employee's Motivation and Satisfaction: An Empirical Study. International Review of Business Research, 5(4), 128-141.

Ben (2014a). Quality Assurance for Effective Agricultural Teacher Preparation and School

Administration in Nigeria .Proceedings of INTCESS14-International Conference on Education and Social Sciences Proceedings.3-5 February 2014- Istanbul, Turkey, 1706 -1712.

Ben (2014b). Improving Agricultural Science Teachers' Work Attitude in Akwa Ibom State of Nigeria: The Financial Initiative Perspective. World Journal of Education, 4(4), 12-19.

Bosompem et al. (2012). Determinants of motivation of senior high school agricultural science teachers in the Central Region, Ghana. Journal of Arts, Science \& Commerce, 3(1), 106-114.

Chamundeswari (2013). Job Satisfaction and Performance of School Teachers.

International Journal of Academic Research in Business and Social Sciences.3 (5), 420-428. Available online at http// www.hrmars.com/journals 
Chiang \& Birtch (2010). Reward climate and its impact on service quality orientation and employee attitudes. International Journal of Hospitality Management, 30(1), 26-37.

Dewhurst, Guthridge \& Mohr (2010). Motivating people: getting beyond Money.

Retrieved May 3th, 2014 from www.samedayessay.com

Diamond (2012). Improving Teaching and learning in Schools. Retrieved May 3th, 2014 from

http/www.tlrp.org/pub/document/TLRP.x

Ehondor \& Omoruyi (2013). An assessment of the problems associated with the teaching/learning of computer science education in a Nigerian institution. Education Research Journal, 3(8), 192-196.

Ferdiman (2007). Personality and personal growth in service. New York: Harper \& Row

Publishers.

Gabrielle \& Hogan (2013). The utilization, deployment, and management of teachers in Malawi, Botswana, South Africa and Uganda. World Journal of Education, 4(4), 20-34.Retrieved May 27, 2014 from information@iiep.unesco.orgwww.sciedu.ca/wje

Gawel (2013). Herzberg's theory of motivation and hygiene factors. Retrieved May 27th,

2014 from http://www.ericdigests.org/1999-1/needs.html

Holmes (2012). Performance management changes: implication for teachers. Retrieved May

30th, 2014 from http://www.optimus-education.com/performancemanagement-changes-implications-teachers-and-cpd

Idio (2008). The impact of substantial investment in education, workforce training, and the

implications on school transformation and economic development in Akwa Ibom state. Educational Leadership, 65(8), 32-39.

Indhumathi (2011). Job Satisfaction, Occupational and Organizational Commitment and Performance of Teachers at the Secondary Level, M.Ed. Thesis, Tamilnadu Teachers Education University, Chennai.

John (2006). Applicability of Maslow's need theory among teachers in Akwa Ibom State:

Implications for educational administration. Unpublished M.Ed Thesis, University of Calabar, Calabar, Nigeria.

Leslie (2014).Linking efficiency to compensation .Retrieved May 27th, 2014 from

http://www.salary.com/productivity-bonuses/

Littlehood (2012). A case study of Public school teachers. Retrieved May 27th, 2014 from 
www.likeessay.com/essays/education

Olukoya (2013). NUT advocates enhanced teachers' welfare. Retrieved May 28th, 2014 from www.teacher.org

Ortyoyande \& Agbe (2005). Motivation and teachers 'quality in schools. Research in Art

Education, 4(3), 14-23.

Shadid (2014). Wages and salary administration. Retrieved from http://www.scribd.com/doc/17295150/Wages-and-Salary-Administration Sirima \& Poipoi (2010). Perceived factors influencing public secondary school

teachers' job satisfaction in Busia District, Kenya. International Research Journal of Educational Research, 1(11), 659-665. 